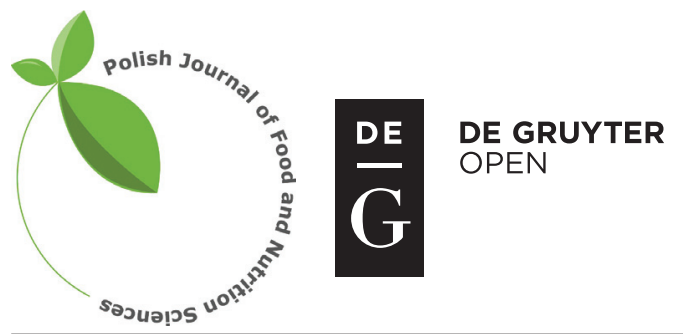

Pol. J. Food Nutr. Sci., 2017, Vol. 67, No. 2, pp. 159-166 DOI: $10.1515 /$ pjfns-2016-0013 http://journal.pan.olsztyn.pl

Original research article

Section: Food Quality and Functionality

\title{
Postharvest Treatments with Methyl Jasmonate and Salicylic Acid for Maintaining Physico-Chemical Characteristics and Sensory Quality Properties of Apricot Fruit during Cold Storage and Shelf-Life
}

\author{
Ahmed Ezzat ${ }^{1,2}$, Amin Ammar , Zoltán Szabó ${ }^{1}$, József Nyéki ${ }^{1}$, Imre J. Holb ${ }^{1,4, *}$ \\ ${ }^{1}$ Institute of Horticulture, University of Debrecen, H-4015 P. O. Box. 36. Debrecen, Hungary \\ ${ }^{2}$ Department of Horticulture, Faculty of Agriculture, Kafrelsheikh University, Egypt \\ ${ }^{3}$ Department of Food Science and Technology, Faculty of Agriculture, Kafelelsehikh University, Egypt \\ ${ }^{4}$ Plant Protection Institute, Centre for Agricultural Research, Hungarian Academy of Sciences, Budapest, Hungary
}

Key words: apricot, methyl jasmonate, salicylic acid, postharvest quality, fruit quality estimation

The aim of this study was to investigate the effect of methyl jasmonate and salicylic acid on 12 quality parameters of apricot fruit in treatments of cold storage $\left(1{ }^{\circ} \mathrm{C}\right.$ for 7,14 and 21 days) and shelf-life ( 4 and 8 days at $25^{\circ} \mathrm{C}$ after a 21 -day cold storage treatment). Fruit quality parameters included 6 physico-chemical characteristics (weight loss, fruit firmness, total soluble solids, acidity, total soluble solids/acidity ratio and juice pH) and 6 sensory properties (skin and flesh colour, texture, taste, visual appearance and overall acceptability). Among physico-chemical characteristics, applications of $0.2 \mathrm{mmol} / \mathrm{L}$ methyl jasmonate and $2 \mathrm{mmol} / \mathrm{L}$ salicylic acid significantly reduced fruit weight loss, fruit softening and juice $\mathrm{pH}$ and maintained soluble solid content and acidity over the whole storage period. Among sensory properties, all parameters were generally increased by methyl jasmonate and salicylic acid treatments compared to water-treated control and the water-treated fruits showed the lowest scores below the acceptability limit except for skin colour. In conclusion, our results suggest using methyl jasmonate and/or salicylic acid to enhance and prolong the storability of apricot fruits during both cold storage and shelf-life period.

\section{INTRODUCTION}

Fruit quality is an essential factor in consumer acceptance for apricot. Apricots as climacteric stone fruits have a limited post-harvest life. They remain fresh only for 2-4 weeks, depending on cultivar, when stored at $0^{\circ} \mathrm{C}$ and they can be stored only up to 5 days in shelf-life conditions at room temperature [Infante et al., 2008; Stanley et al., 2010]. Apricot fruits after harvest and during storage start to lose their physico-chemical quality which is manifested in fruit softening, loss of juiciness and/or gel breakdown, increased fruit acidity and reduction in soluble solid content [Stanley et al., 2010].

Methyl jasmonate (MeJA) and salicylic acid (SA) are endogenous signal molecules that play essential roles in regulating stress responses and plant development [Raskin, 1992; Turner et al., 2002]. MeJA was defined as a natural plant growth regulator and was found to be active in many physiological systems [e.g. Turner et al., 2002]. MeJA was reported to maintain postharvest fruit quality in several tropical fruits such as mango, papaya, guava and pomegranates [González-Aguilar et al., 2000, 2003; Sayyari et al., 2011; Jin et al., 2014] and in temperate fruits such as apple, cherry and peach [Fan et al., 1998; Yao \& Tian, 2005; Meng et al., 2009; Jin et al.,

\footnotetext{
* Corresponding Author: E-mail: holbimre@gmail.com (I. J. Holb) of consumers or growers [Watkins \& Ekman, 2005]. Although

2009]. In these studies, MeJA improved physico-chemical characteristics of fruits but these have not been demonstrated yet for apricot during cold storage or shelf-life periods.

In previous researches, SA significantly reduced quality loss in fruits such as peach [e.g. Li \& Han, 1999; Wang et al., 2006], banana [Srivastava \& Dwivedi, 2000], mandarin [Zheng \& Zhang, 2004], and apricot fruits [Satraj et al., 2013]. SA and its derivatives are widely used to enhance pre- and postharvest quality of fruit such as by controlling firmness of harvested peaches and strawberry during storage [e.g. Li \& Han, 1999; Wang et al., 2006; Valero et al., 2010; Shafiee et al., 2010]. However, effects of SA treatments were investigated only on some physico-chemical and sensorial quality parameters for apricot fruit [Satraj et al., 2013] under a 12-day ambient storage period without presenting sufficient details on storage conditions (e.g. temperature and relative humidity $(\mathrm{RH}))$.

Only one study was performed to compare the effects of MeJA and SA on storability of stone fruits [Yao \& Tian, 2005] but such a comparative study for physico-chemical and sensory quality parameters is not available for apricot fruit either during cold storage or shelf-life.

Sensory estimations are important for packers, transporters, and retailers but they are often quite different from those 
the trade ensures that consumers are presented with products of excellent appearance, texture, flavour and safety but nutritional value and high quality physico-chemical parameters are for instance often ranked lower in importance by marketers [Crisosto et al., 1995; Watkins \& Ekman, 2005]. As a consequence, data on physico-chemical parameters together with sensory quality parameters in the cold storage and shelf-life periods can give stable and valuable information for all partners of fruit industry including growers, transporters, retailers and consumers.

The aim of this study was to investigate the effects of MeJA and SA on 12 apricot fruit quality parameters in treatments of cold storage $\left(1^{\circ} \mathrm{C}\right.$ for 7,14 and 21 days) and shelf-life ( 4 and 8 days at $25^{\circ} \mathrm{C}$ after a 21 -day cold storage treatment). The 12 attributes were classified into two groups: physico-chemical characteristics (weight loss, fruit firmness, total soluble solids (TSS), acidity, TSS/acidity ratio and juice $\mathrm{pH}$ ) and sensory properties (skin and flesh colour, texture, taste, visual appearance and overall acceptability).

\section{MATERIALS AND METHODS}

\section{Fruit material and treatment}

Fruits of apricot cultivar 'Bergarouge' were hand harvested in a commercial orchard in Boldogkőváralja, Hungary, at ripe stage and selected for uniform size $(40 \mathrm{~mm})$, colour and examined to exclude all visual defects.

The harvested fruits were divided into three groups (each group containing 150 fruits, altogether $3 \times 150=450$ fruits) According to our preliminary unpublished research on three concentrations of MeJA (0.1, 0.2 and $0.4 \mathrm{mmol} / \mathrm{L})$ and SA $(0.5,1,2 \mathrm{mmol} / \mathrm{L}$ for $\mathrm{SA})$, the most effective concentrations of $0.2 \mathrm{mmol} / \mathrm{L} \mathrm{MeJA}$ and $2 \mathrm{mmol} / \mathrm{L} \mathrm{SA}$ were selected for this detailed study. Fruits were dipped into a solution of $0.2 \mathrm{mmol} / \mathrm{L} \mathrm{MeJA}$ and $2 \mathrm{mmol} / \mathrm{L} \mathrm{SA}$ for $15 \mathrm{~min}$ as well as control fruits were submerged into distilled water. Then for each treatment, fruits were divided into 2 further groups. The first group, as the cold storage treatment, was stored at $1^{\circ} \mathrm{C}$ and examinations were done on days 7, 14 and 21 (including $3 \times 90$ fruits). The second group, as the shelf-life treatment, was stored at $1{ }^{\circ} \mathrm{C}$ and $95 \%$ humidity for 21 days then placed at room temperature $\left(25^{\circ} \mathrm{C}\right)$ and fruits were examined at days 4 and 8 (including $3 \times 60$ fruits). Each treatment was replicated three times (including $3 \times 450$ fruits $=$ 1350 fruits) and experiments were repeated twice (including altogether $2 \times 1350$ fruits).

\section{Physico-chemical characteristics}

Measurements for weight loss, fruit firmness, TSS, acidity, TSS/acidity ratio and juice $\mathrm{pH}$ were performed on 30 fruits in three replicates from day 0 (harvest) until each assessment date of the cold storage and shelf-life treatments. Weight loss was expressed as percentage loss of the initial weight using a digital balance (BL S3102 Precision Balance, Bel Engineering, Italy). Fruit firmness was determined destructively using a Magness-Taylor (M-T) fruit penetrometer tester mounted in a drill press to control the movement (model FT011; Facchini Francesco Srl, Brescia, Italy). The firmness of each fruit was measured on opposite sides of the equator to give two readings per fruit. Results from destructive tests were means of 30 recorded fruits. Juice sample was obtained by choking with a mortar and pestle and filtrated with cheese cloth. TSS were measured in the juice of each sample with a digital refractometer (model 53007 TR, TR-Turoni Inc Forli, Italy) at $25^{\circ} \mathrm{C}$ and results are the means expressed in percentage as ( ${ }^{\circ}$ Brix). Juice acidity (\%) was measured by portable acidity meter (model 53101 TR, TR-Turoni Inc Forli, Italy) then the TSS/acidity ratio was calculated. $\mathrm{pH}$ measurements were performed using a pH meter (84432 HANNA Instruments, Germany).

\section{Sensory quality attributes}

Sensory evaluation of 30 apricot fruits was performed by a sensory panel of eight trained judges independently at each assessment date of both cold storage and shelf-life treatments. Panellists were asked to evaluate skin colour, flesh colour, texture, taste, visual appearance and overall acceptability. Measurements were assessed according to the method of Infante et al. [2008] and Muftuoğlu et al. [2012]. Our evaluation guide provided a continuous scale for each sensory attribute, ranging from 0 to 9 , and marked with two anchors (skin and flesh colour: $0=$ unacceptable, $9=$ excellent; texture: $0=$ very soft, 9 = very hard; taste: $0=$ bad taste and $9=$ excellent taste; visual appearance: $0=$ very bad, $9=$ excellent; and overall acceptability: 0 = unacceptable, $9=$ excellent). Scores of 5 or above were considered acceptable for commercial purposes.

\section{Statistical analysis}

Experiments were performed using a completely randomised design. The data were subjected to analysis of variance using SPSS program (SPSS Inc., Chicago, IL, USA). The effects of chemical treatment (control, MeJA and SA), storage type (cold storage and shelf-life) and their interactions on each parameter for physico-chemical characteristics and sensory quality were evaluated. Means separation was performed by Duncan's multiple range tests. Differences at $P<0.05$ were considered as significant.

\section{RESULTS AND DISCUSSION}

\section{Weight loss}

Apricot fruits lost weight either during cold storage or shelf-life treatment (Figure 1A). In the cold storage treatment, weight reduction in the control treatment was significantly higher $(P<0.05)$ at days 14 and 21 compared with treatments of $0.2 \mathrm{mmol} / \mathrm{L} \mathrm{MeJA}$ and $2 \mathrm{mmol} / \mathrm{L} \mathrm{SA}$. In the shelf-life treatment, significant differences between control and chemically-treated fruit occurred at both dates (day 4 and 8) at $25^{\circ} \mathrm{C}$ (Figure 1B). The SA and MeJA treatments alleviated weight loss of fruits almost equally (between 2 and $6 \%$ ) in both cold storage and shelf-life conditions.

The anti-senescent action and maintenance of cellular integrity by both MeJA and SA in the present study might be the reason in lowering weight loss of apricot in both cold storage and shelf-life conditions. These findings for SA were supported on different fruit crops [e.g. Zheng \& Zhang, 2004; Shafiee et al., 2010; Valero et al., 2011; Satraj et al., 2013]. Zheng \& Zhang [2004] showed that SA reduced fruit weight 

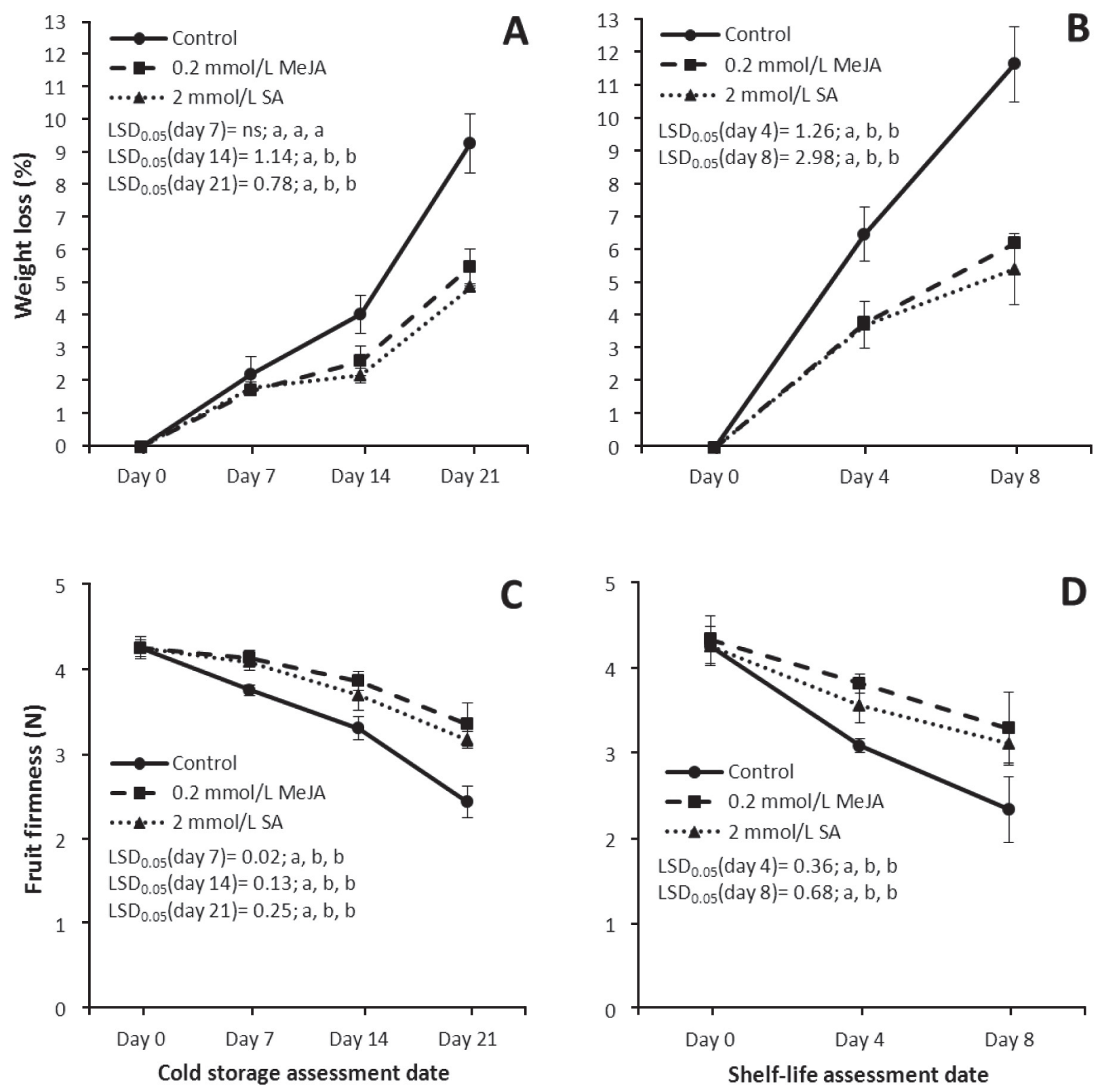

FIGURE 1. Effect of $0.2 \mathrm{mmol} / \mathrm{L}$ methyl jasmonate (MeJA) and $2 \mathrm{mmol} / \mathrm{L}$ salicylic acid (SA) on weight loss percentage and fruit firmness (N) of apricot fruit (cv. 'Bergarouge') in cold storage treatment at days 7,14 and 21 at $1{ }^{\circ} \mathrm{C}\left(\mathrm{A}\right.$ and $\mathrm{C}$ ), and in shelf-life treatment at days 4 and 8 at $25^{\circ} \mathrm{C}$ (B and D). Error bars represent the $\mathrm{SD}$ values. $\mathrm{LSD}_{0.05}$ values are given for each assessment date and for each treatment at $P<0.05$. 1st, 2 nd and $3 \mathrm{rd}$ letters given after each $\mathrm{LSD}_{005}$ value belong to treatments in the order of control, MeJA and SA treatments, respectively; and if these letters are different, corresponding treatments are significantly different from each other at $P<0.05$.

loss by closing stomata of cultivar 'Ponkan' mandarin fruit. Shafiee et al. [2010] found that SA was effective in reducing weight loss of strawberry when applied either in nutrient solution or dipping treatment after postharvest. Valero et al. [2011] reported that SA was effective in reducing weight loss of sweet cherry during cold storage. The only apricot study [Satraj et al., 2013] demonstrated that treatments with $2 \mathrm{mmol} / \mathrm{L} \mathrm{SA}$ resulted in the lowest fruit weight loss (approx. 8\%) among four different SA treatments after an 8-day ambient store condition. In our study, a lower weight loss was detected (approx. $5 \%$ ) in the $2 \mathrm{mmol} / \mathrm{L} \mathrm{SA}$ treatment after 8-day shelf-life storage conditions $\left(22^{\circ} \mathrm{C}\right)$. This may be due to differences in cultivar features and store conditions though details on storage conditions (e.g. temperature and relative humidity $(\mathrm{RH}))$ were not available in the study of Satraj et al. [2013].

In contrast with our study, MeJA treatments $(0.01$ or $0.1 \mathrm{mmol} / \mathrm{L}$ ) did not modify the water loss of papaya fruit either after cold storage $\left(32\right.$ days $\left.10^{\circ} \mathrm{C}\right)$ or shelf-life (4 days $20^{\circ} \mathrm{C}$ ) [González-Aguliar et al., 2003], while in our study $0.2 \mathrm{mmol} / \mathrm{L} \mathrm{MeJA}$ significantly reduced water loss of apricot both in cold storage and shelf-life conditions. Apart from the different storage conditions and fruit species of the two studies, the significant weight loss reduction in our study is likely to be due to the use of a higher MeJA concentration. However, similarly to our study, Jin et al. [2014] showed that MeJA treatment $(16 \mu \mathrm{mol})$ could maintain lower value 

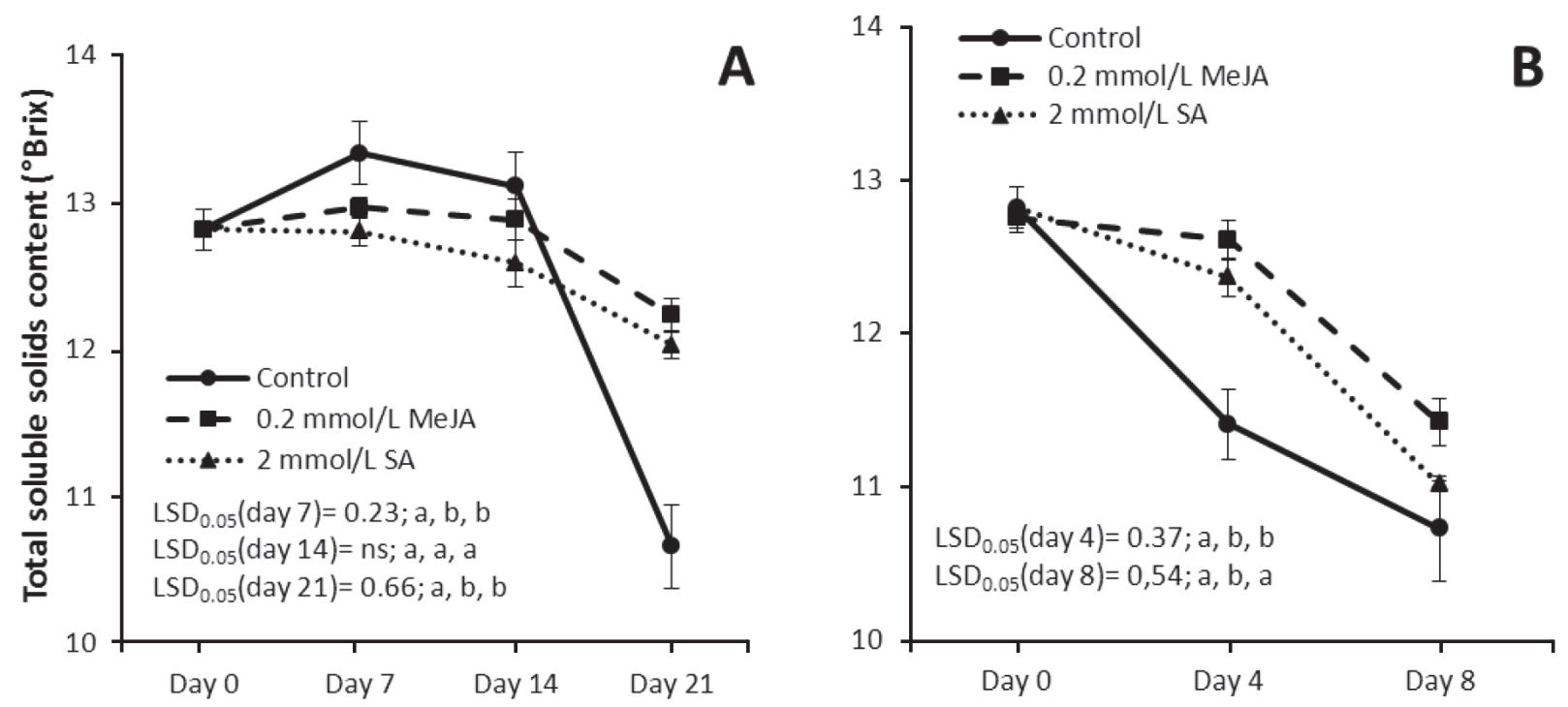

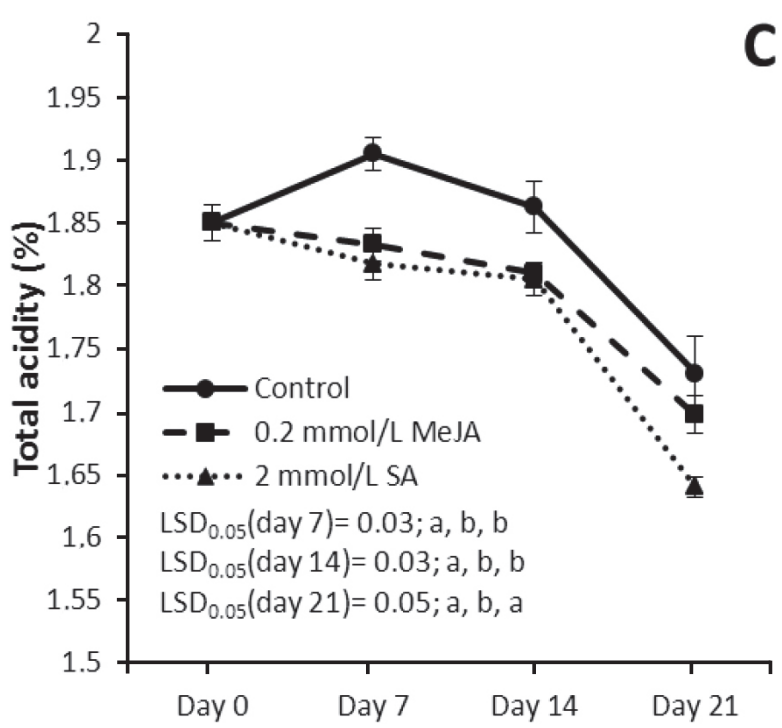

Cold storage assessment date

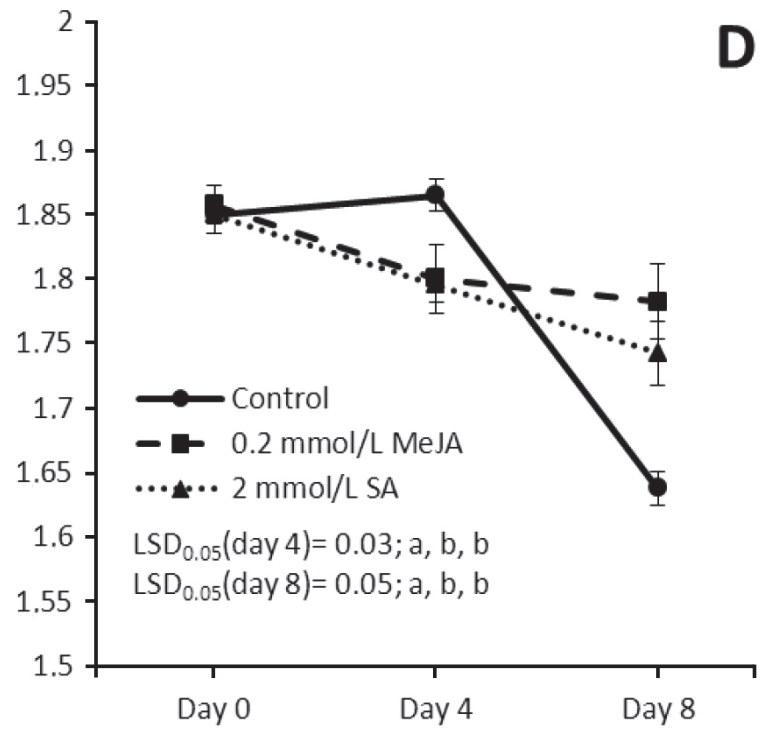

Shelf-life assessment date

FIGURE 2. Effect of $0.2 \mathrm{mmol} / \mathrm{L}$ methyl jasmonate (MeJA) and $2 \mathrm{mmol} / \mathrm{L}$ salicylic acid (SA) on total soluble solids (TSS, ${ }^{\circ}$ Brix), total acidity (\%), TSS/acidity ratio and juice $\mathrm{pH}$ of apricot fruit (cv. 'Bergarouge') in cold storage treatment at days 7, 14 and 21 at $1{ }^{\circ} \mathrm{C}(\mathrm{A}, \mathrm{C}, \mathrm{E}$, and $\mathrm{G})$, and in shelf-life treatment at days 4 and 8 at $25^{\circ} \mathrm{C}(\mathrm{B}, \mathrm{D}, \mathrm{F}$, and $\mathrm{H})$. Other explanations for error bars and $\mathrm{LSD}_{0.05}$ values are given in the title of Figure 1.

of weight loss of loquat fruit compared with the control after a 35 -day storage at $1^{\circ} \mathrm{C}$ plus 3 -day shelf-life at $20^{\circ} \mathrm{C}$.

\section{Fruit firmness}

Fruit firmness decreased in all treatments for both cold storage and shelf-life conditions but values of fruit firmness were significantly higher $(P<0.05)$ in all assessment dates for both MeJA and SA treatments compared to the water-treated fruits (Figure 1CD). The fruit firmness differences between SA and MeJA treatments were not significant in either cold storage or shelf-life conditions.

In our study, MeJA treatments maintained apricot fruit firmness compared to control treatments (Figure 1CD), which was in agreement with previous studies for instance on papaya [González-Aguliar et al., 2003], peach [Meng et al., 2009] and pomegranates [Sayyari et al., 2011]. However, some previous studies showed that MeJA did not affect the firmness compared to control treatments or treatments without MeJA; for instance, on apple stored for 1 week at $20^{\circ} \mathrm{C}$ and 80 days at $4^{\circ} \mathrm{C}$ [Fan et al., 1998], on mango during cold storage and shelf-life [González-Aguilar et al., 2000], on peaches after a 3-day shelf-life [Meng et al., 2009] and again on peaches after 3 or 5 weeks of cold storage plus a 3-day shelf-life at $20^{\circ} \mathrm{C}$ [Jin et al., 2009]. In addition, Jin et al. [2014] showed that loquat fruit firmness was lower in $16 \mu$ mol MeJA treatment compared with the control after a 35 -day storage at $1^{\circ} \mathrm{C}$ plus a 3 -day shelf-life at $20^{\circ} \mathrm{C}$. Different firmness responses of stored fruit to MeJA treatments indicates that this measure may be related to several factors such as fruit species, MeJA concentrations, and storage conditions. In our study, the two 

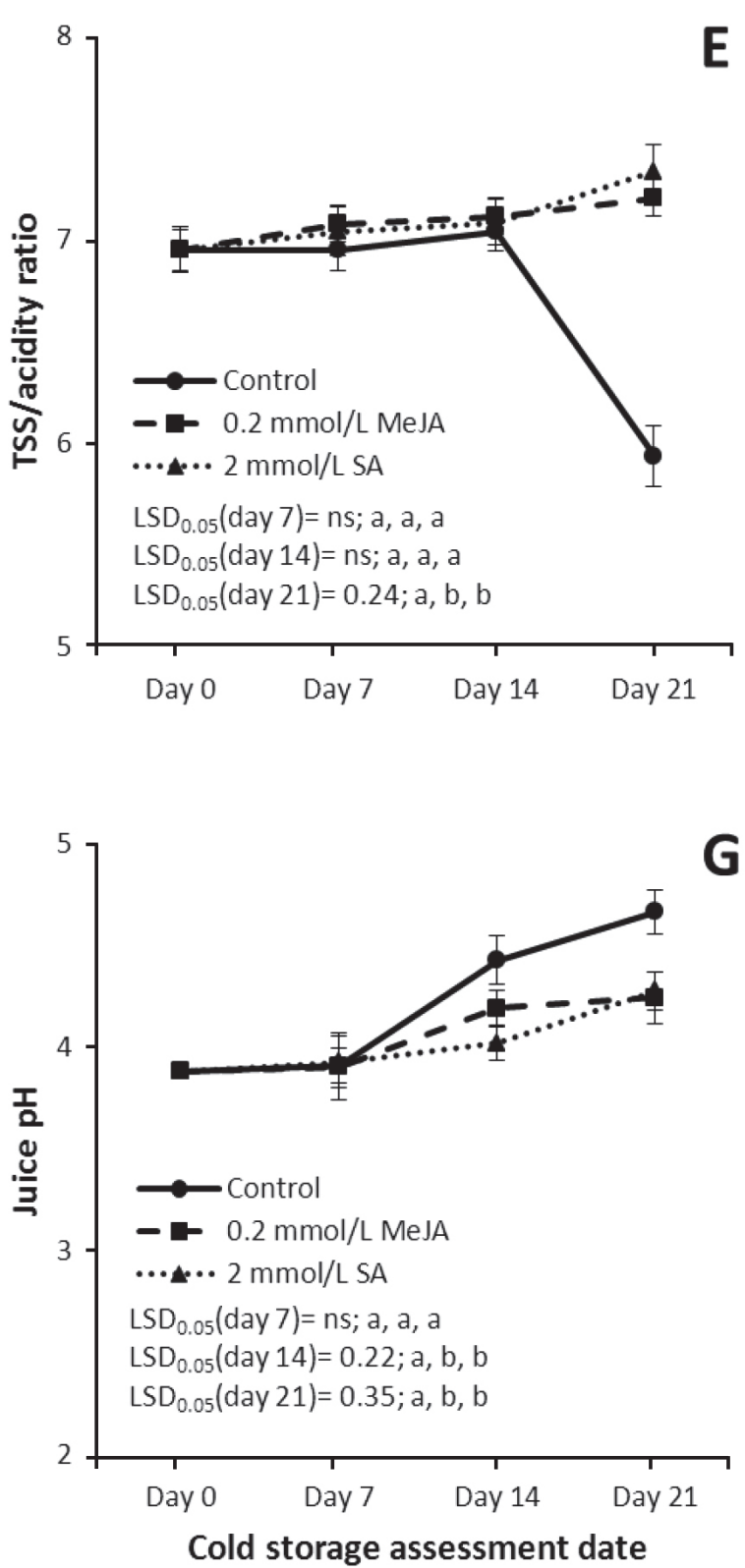

FIGURE 2. continued

storage types did not change fruit response to MeJA treatments on apricot fruit firmness (Figure 1 CD). However, some previous studies on apple and peach fruit showed differences of MeJA efficacy under cold storage or shelf life conditions [Fan et al., 1998; Meng et al., 2009]. This was not the case in our apricot study which may be due to the use of a higher and more effective concentration of MeJA.

SA treatments were effective to maintain apricot fruit firmness in this study compared to control treatments (Figure $1 C D$ ). SA in general has been found effective in retarding the senescence of fruit tissue, delaying the ripening process and evolution of ethylene, as a consequence to enhance flesh firmness for instance banana fruits during ripening [Srivastava \& Dwivedi, 2000], peaches during storage [Li \& Han 1999; Wang et al., 2006] and strawberry [Ayala-Zavala et al.,
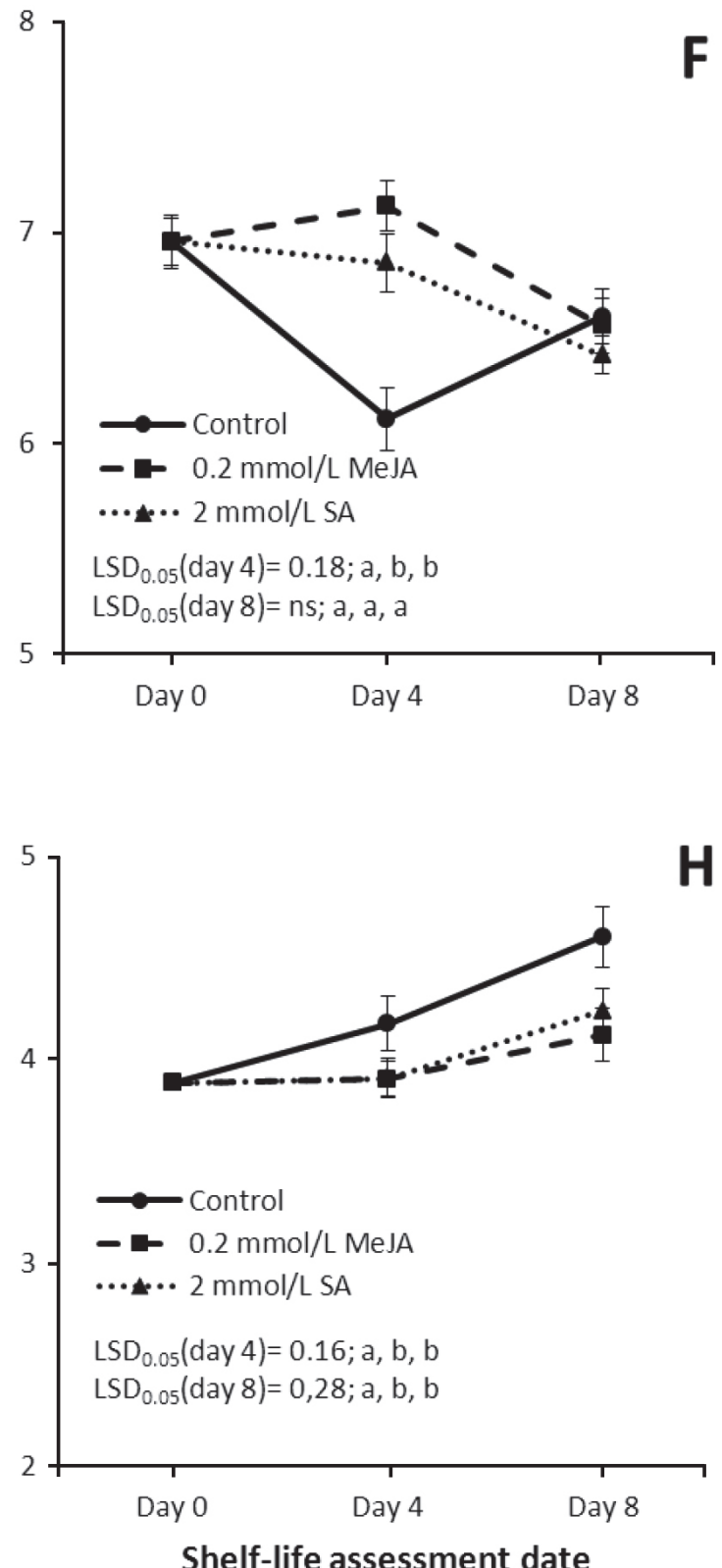

2005]. A research by Wang et al. [2006] on peaches showed that firmness of fruit treated with $1 \mathrm{mmol} / \mathrm{L} \mathrm{SA}$ was significantly greater than that of control fruit; however the firmness of fruit treated with 0.35 or $0.7 \mathrm{mmol} / \mathrm{L} \mathrm{SA}$ was not different from that of the control fruit. Shafiee et al. [2010] showed that SA application in nutrient solution and dipping treatment after harvest improved fruit firmness in strawberry. Sayyari et al. [2011] showed that methyl salicylate (MeSA) treatment on pomegranates fruit delayed the softening process under chilling temperature for 84 days. More recently, Satraj et al. [2013] in their study on apricot demonstrated that $2 \mathrm{mmol} / \mathrm{L}$ SA showed the highest fruit firmness (approx. $5 \mathrm{~N}$ ) among four different SA treatments after an 8-day ambient store condition. In our study, a lower firmness (approx. 3-3.5N) was detected in the $2 \mathrm{mmol} / \mathrm{L} \mathrm{SA}$ treatment after 21 -day cold stor- 
TABLE 1. Effect of treatments of $0.2 \mathrm{mmol} / \mathrm{L}$ methyl jasmonate (MeJA) and $2 \mathrm{mmol} / \mathrm{L}$ salicylic acid (SA) on 6 sensory properties of cv. 'Bergarouge' apricot fruits.

\begin{tabular}{|c|c|c|c|c|c|c|c|}
\hline \multirow{2}{*}{ Parameters" } & \multirow{2}{*}{ Chemical treatment } & \multicolumn{4}{|c|}{ Cold storage assessment date } & \multicolumn{2}{|c|}{ Shelf-life assessment date } \\
\hline & & day 0 & day 7 & day 14 & day 21 & day 4 & day 8 \\
\hline \multirow{3}{*}{ Skin colour } & Control & $7.20^{\mathrm{aA}^{*}}$ & $7.83^{\mathrm{aA}}$ & $7.95^{\mathrm{bB}}$ & $7.56^{\mathrm{bB}}$ & $7.10^{\mathrm{aC}}$ & $7.67^{\mathrm{bB}}$ \\
\hline & MeJA & $7.20^{\mathrm{aA}}$ & $7.40^{\mathrm{aB}}$ & $6.50^{\mathrm{aA}}$ & $6.10^{\mathrm{aA}}$ & $6.20^{\mathrm{aB}}$ & $6.30^{\mathrm{aA}}$ \\
\hline & SA & $7.20^{\mathrm{aA}}$ & $7.90^{\mathrm{aB}}$ & $6.80^{\mathrm{aA}}$ & $6.20^{\mathrm{aA}}$ & $6.00^{\mathrm{aB}}$ & $6.40^{\mathrm{aA}}$ \\
\hline \multirow{3}{*}{ Flesh colour } & Control & $8.00^{\mathrm{aA}}$ & $4.20^{\mathrm{bB}}$ & $3.90^{\mathrm{cB}}$ & $3.10^{\mathrm{cB}}$ & $2.20^{\mathrm{dB}}$ & $1.90^{\mathrm{dB}}$ \\
\hline & MeJA & $8.00^{\mathrm{aA}}$ & $7.30^{\mathrm{aA}}$ & $6.90^{\mathrm{aA}}$ & $5.30^{\mathrm{bA}}$ & $6.20^{\mathrm{bA}}$ & $4.30^{\mathrm{cA}}$ \\
\hline & SA & $8.00^{\mathrm{aA}}$ & $7.09^{\mathrm{aA}}$ & $6.30^{\mathrm{bA}}$ & $5.30^{\mathrm{bA}}$ & $5.90^{\mathrm{bA}}$ & $4.10^{\mathrm{cA}}$ \\
\hline \multirow{3}{*}{ Texture } & Control & $8.90^{\mathrm{aA}}$ & $5.20^{\mathrm{bB}}$ & $4.30^{\mathrm{bC}}$ & $2.90^{\mathrm{cB}}$ & $4.30^{\mathrm{bB}}$ & $3.10^{\mathrm{cC}}$ \\
\hline & MeJA & $8.90^{\mathrm{aA}}$ & $7.10^{\mathrm{aA}}$ & $6.10^{\mathrm{bA}}$ & $4.30^{\mathrm{cA}}$ & $6.10^{\mathrm{bA}}$ & $4.10^{\mathrm{cB}}$ \\
\hline & SA & $8.90^{\mathrm{aA}}$ & $6.90^{\mathrm{aA}}$ & $5.20^{\mathrm{bB}}$ & $4.70^{\mathrm{cA}}$ & $6.30^{\mathrm{bA}}$ & $5.10^{\mathrm{cA}}$ \\
\hline \multirow{3}{*}{ Taste } & Control & $7.80^{\mathrm{aA}}$ & $4.30^{\mathrm{bB}}$ & $3.10^{\mathrm{cB}}$ & $2.30^{\mathrm{cB}}$ & $3.90^{\mathrm{bB}}$ & $2.90^{\mathrm{cA}}$ \\
\hline & MeJA & $7.80^{\mathrm{aA}}$ & $6.90^{\mathrm{aA}}$ & $5.30^{\mathrm{bA}}$ & $3.90^{\mathrm{cA}}$ & $5.20^{\mathrm{bA}}$ & $3.10^{\mathrm{cA}}$ \\
\hline & SA & $7.80^{\mathrm{aA}}$ & $7.10^{\mathrm{aA}}$ & $5.20^{\mathrm{bA}}$ & $4.20^{\mathrm{cA}}$ & $5.30^{\mathrm{bA}}$ & $3.20^{\mathrm{cA}}$ \\
\hline \multirow{3}{*}{ Visual appearance } & Control & $7.30^{\mathrm{aA}}$ & $4.50^{\mathrm{bB}}$ & $3.90^{\mathrm{bB}}$ & $2.90^{\mathrm{cC}}$ & $2.70^{\mathrm{cB}}$ & $1.70^{\mathrm{dB}}$ \\
\hline & MeJA & $7.30^{\mathrm{aA}}$ & $6.80^{\mathrm{aA}}$ & $5.90^{\mathrm{bA}}$ & $3.80^{\mathrm{cB}}$ & $5.50^{\mathrm{bA}}$ & $3.80^{\mathrm{cA}}$ \\
\hline & SA & $7.30^{\mathrm{aA}}$ & $7.10^{\mathrm{aA}}$ & $5.90^{\mathrm{bA}}$ & $4.90^{\mathrm{cA}}$ & $5.20^{\mathrm{bA}}$ & $4.30^{\mathrm{cA}}$ \\
\hline \multirow{3}{*}{ Overall acceptability } & Control & $8.00^{\mathrm{aA}}$ & $4.10^{\mathrm{bB}}$ & $3.20^{\mathrm{cB}}$ & $1.80^{\mathrm{dB}}$ & $2.10^{\mathrm{dC}}$ & $1.20^{\mathrm{dC}}$ \\
\hline & MeJA & $8.00^{\mathrm{aA}}$ & $6.20^{\mathrm{bA}}$ & $5.30^{\mathrm{bA}}$ & $3.90^{\mathrm{cA}}$ & $5.30^{\mathrm{bB}}$ & $4.20^{\mathrm{cB}}$ \\
\hline & SA & $8.00^{\text {Аа }}$ & $6.40^{\mathrm{bA}}$ & $5.70^{\mathrm{bA}}$ & $4.20^{\mathrm{cA}}$ & $6.10^{\mathrm{bA}}$ & $4.20^{\mathrm{bA}}$ \\
\hline
\end{tabular}

\# Scale for all the 6 sensory parameters ranged from 0 to 9 , and were marked with two anchors (skin and flesh colour: $0=$ unacceptable, $9=$ excellent; texture: $0=$ very soft, $9=$ very hard; taste: $0=$ bad taste and $9=$ excellent taste; visual appearance: $0=$ very bad, $9=$ excellent; and overall acceptability: $0=$ unacceptable, $9=$ excellent.

* For each parameter (row), different small letters in superscript indicate significant differences at $P<0.05$ among storage treatments. For each column, different capital letters in superscript indicate significant differences at $P<0.05$ among chemical treatments for each measured parameter.

age $\left(1^{\circ} \mathrm{C}\right)$ and after 8 -day shelf life storage conditions $\left(22^{\circ} \mathrm{C}\right)$ which may be due to differences in cultivar features and storage conditions.

In our study, both MeJA and SA treatments maintained apricot fruit firmness compared to control treatments (Figure $1 \mathrm{CD}$ ) with the effect being slightly higher for MeJA than SA in both cold storage and shelf-life treatments. The study of Sayyari et al. [2011] on pomegranates was the only report which demonstrated that both MeJA and MeSA treatments delayed the softening process, but in contrast with our result, the effect was slightly higher for MeSA than MeJA.

\section{TSS, total acidity, TSS/acidity ratio and juice pH}

For each treatment, TSS, total acidity, and TSS/acidity ratio were similar from day 0 to 14 in the cold storage treatment (Figure 2ACE). Then all treatments showed a decrease in TSS, total acidity and TSS/acidity ratio between day 14 and 21 (Figure 2ACE) except for MeJA and SA treatments for TSS/acidity ratio (Figure 2E). In the shelf-life treatments, the TSS, total acidity and TSS/acidity ratio decreased in all treatments with time (Figure 2BDF) except for control treatments for TSS/acidity ratio (Figure 2F). Juice $\mathrm{pH}$ increased in all treatments with time but the increase was significantly lower $(P<0.05)$ in both the MeJA and the SA treatments compared to water-treated fruit after day 7 and day 4 , for cold storage and the shelf-life treatments, respectively (Figure 2GH).

Due to the action of the key enzyme, sucrose-phosphate synthase (SPS), in sucrose biosynthesis, TSS and soluble sugars are likely to increase during fruit maturity [Hubbard et al., 1991]. Recently, Aghdam et al. [2011] showed that MeSA decreased the ethylene production and SPS enzyme activity, resulting in a reduction of TSS and sucrose biosynthesis. Cell walls contain mainly the polysaccharides of pectins and cellulose, and these are digested by the cell wall degrading enzymes resulting in an increased amount of TSS. Asgharia \& Aghdam [2010] demonstrated that SA reduced the activity of cell wall degrading enzymes, thus SA also reduced TSS content of fruit as it was also shown in our shelf-life treatments (Figure 2) and in the study of Satraj et al. [2013]. However, a previous research of Sayyari et al. [2011] showed that SA treatments did not change significantly the content of TSS and total acids during storage for pomegranate fruits. These results are in agreement with our results found in the first 14 days of the cold storage treatments. 
Previous research showed that MeJA significantly increased sugar and acid contents in strawberry compared to water-treated control fruit [Ayala Zavala et al., 2005]. Jin et al. [2009] showed that MeJA treatments maintained a high level of TSS and total acids of peach fruit in a combined cold storage and shelf-life treatments. In addition, Meng et al. [2009] showed that $0.1 \mathrm{mmol} / \mathrm{L} \mathrm{MeJA}$ treatment not only enhanced the rate of TSS/acidity in peach fruits but also affected the degradation of cell wall, perhaps by regulation of cell wall modifying enzymes and the calcium content in cell wall of flesh. In our research, SA and MeJA showed higher TSS/acidity ratio than the control treatment $(P<0.05$; Figure 2). Low acidity levels were accompanied with a firmer apricot fruits in both SA and MeJA treatments of our study, which may be due to a decrease in pectin solubilisation. Softening starts with the conversion of insoluble protopectin into water-soluble pectin, which results in increasing juice acidity. This will eventually result in cell wall deterioration [Fishman et al., 1993]. Banana fruits treated with SA showed increased fruit firmness and decreased activity of cell wall degrading enzymes [Srivastava \& Dwivedi, 2000]. This can also be hypothesised in our apricot study as acidity was raised in the control fruit (Figure 2) with decreasing fruit firmness (Figure 1). In addition, small weight loss in chemically-treated fruits resulted in high firmness and lower $\mathrm{pH}$ levels, which may be due to that SA reduced respiration rates of treated fruit [Srivastava \& Dwivedi, 2000]. This phenomenon can be seen in this study for apricot SA and MeJA treatments in Figures 1 and 2.

\section{Sensory quality parameters}

Scores of all sensory quality parameters decreased in storage time for all the treatments (Table 1). Generally, the water-treated fruits received most scores below the acceptability limit (point 5) compared to MeJA and SA treatments, except for skin colour (Table 1). All sensory quality parameters (except for skin colour) were below 5 in the control treatments at days 14 and 21 in the cold storage and days 4 and 8 in the shelf-life treatments. Skin colour was above acceptability limit in all treatments and this parameter was significantly higher in the control treatments compared to the two chemical treatments at days 14 and 21 in the cold storage and days 4 and 8 in the shelf-life treatments. All other sensory quality parameters were above 5 in both the MeJA and the SA treatments, except for day 21 in the cold storage and day 8 in the shelf-life treatments. Sensory quality parameters of flesh colour, texture, taste, visual appearance and overall acceptability were significantly higher in the MeJA and and SA treatments compared to control treatments at days 14 and 21 in the cold storage and at days 4 and 8 in the shelf-life treatments. Sensory quality parameters were not significantly different between MeJA and SA treatments. Overall, all sensory quality parameters were increased by MeJA and SA treatments compared to water-treated control except for skin colour.

Hegedűs et al. [2011] showed that the fruit skin lightness factor increased during the whole fruit maturity period. Majority of this increase overlapped with the early fruit maturity period which could be typified by a chlorophyll degradation profile in fruits. This can be the reason why con- trol fruit showed a more intensive fruit colour compared to the treated fruits as SA and MeJA were reported to delay fruit ripening and consequently colouring [Srivastava \& Dwivedi, 2000; Aghdam et al., 2011]. However, Ayala Zavala et al. [2005] in their study on strawberry showed no differences in skin colour among MeJA and control treatments, whereas Muftuoğlu et al. [2012] demonstrated that control fruit received the lowest scores for skin colour.

Obenland et al. [2009] reported that a sugar/acid ratio is an important factor in determining consumer acceptance as sugar provides sweetness and organic acids sourness. A slight decrease in taste score of SA and/or MeJA treatments in this study may due to the reduction in conversion of starch/ organic acid into sugars. Physico-chemical characteristics such as contents of sugars and organic acids and their ratios are known to correlate with several sensory properties of fruits [Colaric et al., 2005]. The degradation of structural polysaccharides and carbohydrates into other simple compounds was reported as a reason for the reduction of fruit taste at later stage during storage [Colaric et al., 2005]. This can explain why control fruit received an extremely low score for taste after 2 weeks of cold storage as at the same time TSS decreased sharply (Figure 2).

The reduction of fruit texture in this study may be due to the degradation of pectin substance which resulted in a low texture score for control. Previous studies showed that MeJA reduced pectin-methyl-esterase (PME) activity to decrease de-esterification of pectin [Meng et al., 2009], and hence maintained fruit texture. SA has been documented to enhance flesh firmness of harvested peaches during storage [Wang et al., 2006].

The loss in overall acceptability scores of apricot fruit during storage may be due to degradation of different parameters. Colour, aroma, taste and texture are degraded due to browning, moisture losses, and breakdown of sugars, acids and volatile compounds [Crisosto et al., 1995]. The ability of SA or MeJA to keep the overall acceptability better than control treatment resulted in keeping most of physical parameters unchanged during storage. Our results were in agreement with Satraj et al. [2013], who reported that the use of SA improved fresh market traits of apricot during ambient storage and may help to increase marketing options of apricot fruit.

\section{SUMMARY AND CONCLUSION}

This study investigated the effect of MeJA and SA on 6 physico-chemical characteristics and 6 sensory properties of postharvest fruit quality of apricot in cold storage and shelf-life conditions. Our data indicated that treatments with SA or MeJA reduced fruit weight loss, fruit softening, juice $\mathrm{pH}$, and maintained soluble solid content and acidity. In addition, both treatments increased sensory quality parameters including flesh colour, taste, texture, visual appearance and overall acceptability. Since MeJA and SA treatments are easy to set up and inexpensive, it could be a useful technique to maintain physico-chemical and sensory quality parameters of apricot fruit. In conclusion, our results suggest using MeJA and/or SA to enhance and prolong the storability of apricot fruits during both cold storage and shelf-life period. 


\section{RESEARCH FUNDING}

This study was supported by a grant of the Hungarian Research Science Found K108333.

\section{CONFLICT OF INTEREST}

Authors declare no conflict of interest.

\section{REFERENCES}

1. Aghdam M.S., Mostofi Y., Motallebiazar A., Ghasemneghad M., Fattahi M.J., Methyl salicylate affects the quality of 'Hayward' kiwifruits during storage at low temperature. J. Agric. Sci., 2011, 3, 149-156.

2. Asghari M., Aghdam M.S., Impact of salicylic acid on post-harvest physiology of horticultural crops. Trends Food Sci. Technol., 2010, 21, 502-509.

3. Ayala-Zavala J.F., Wang S.Y., Wang C.Y., González-Aguilar G.A., Methyl jasmonate in conjunction with ethanol treatment increases antioxidant capacity, volatile compounds and postharvest life of strawberry fruit. Eur. Food Res. Technol., 2005, 221, 731-738.

4. Colaric M., Veberic R., Stampar F., Hudina M., Evaluation of peach and nectarine fruit quality and correlation between sensory and chemical attributes. J. Sci. Food Agric., 2005, 85, 2611-2616.

5. Crisosto C.H., Mitchell F.G., Johnson R.S., Factors in fresh market stone fruit quality. Postharv. News Inform., 1995, 6(2), 17N-21N.

6. Fan X., Mattheis J.P., Fellman J.K., Responses of apples to postharvest jasmonate treatments. J. Amer. Soc. Hortic. Sci., 1998, 123, 421-425.

7. Fishman M.L., Levaj B., Gillespie D., Scorza R., Changes in the physicochemical properties of peach fruit pectin during on-tree ripening and storage. J. Amer. Soc. Hortic. Sci., 1993, $118,343-349$.

8. González Aguilar G.A., Buta J.G.,Wang C.Y., Methyl jasmonate and modified atmosphere packaging (MAP) reduce decay and maintain post harvest quality of papaya 'Sunrise'. Postharv. Biol. Technol., 2003, 28, 361-370.

9. González-Aguilar G.A., Fortiz J., Cruz R., Baez R., Wang C.Y., Methyl jasmonate reduces chilling injury and maintains postharvest quality of mango fruit. J. Agric. Food Chem., 2000, 48, 515-519.

10. Hegedűs A., Pfeiffer N., Papp N., Abrankó L., Blázovics A., Pedryc A., Stefanovits-Bányai E., Accumulation of antioxidants in apricot fruit through ripening: Characterization of a genotype with enhanced functional properties. Biol. Res., 2011, 44, 339-344.

11. Hubbard NL., Pharr DM., Huber SC., Sucrose phosphate synthase and other sucrose metabolizing enzymes in fruits of various species. Physiol. Plant., 1991, 82, 191-196.

12. Infante R., Meneses C., Defilippi B.G., Effect of harvest maturity stage on the sensory quality of 'Palsteyn' apricot (Prunus armeniaca L.) after cold storage. J. Hortic. Sci. Biotechnol., 2008, 83, 828-832.

13. Jin P, Duan Y., Wang L., Wang J., Zheng Y., Reducing chilling injury of loquat fruit by combined treatment with hot air and methyl jasmonate. Food Bioprocess Technol., 2014, 7, 2259-2266.

14. Jin P., Wang K., Shang H., Tong J., Zheng Y., Low temperature conditioning combined with methyl jasmonate treatment reduc- es chilling injury of peach fruit. J. Sci. Food Agric., 2009, 89, 1690-1696.

15. Li L.P., Han T., The effects of salicylic acid in the storage of peach. Food Sci., 1999, 7, 61-63.

16. Meng X., Han J., Wang Q., Tian S.P., Changes in physiology and quality of peach fruits treated by methyl jasmonate under low temperature stress. Food Chem., 2009, 114, 1028-1035.

17. Muftuoğlu F., Ayhan Z., Okan Esturk O., Modified atmosphere packaging of 'Kabaaşı' apricot (Prunus armeniaca L. 'Kabaaşı'): effect of atmosphere, packaging material type and coating on the physicochemical properties and sensory quality. Food Bioprocess Technol., 2012, 5, 1601-1611.

18. Obenland D., Collin S., Mackey B., Sievert J., Fjeld K., Arpaia M.L., Determinants of flavor acceptability during the maturation of navel oranges. Postharv. Biol. Technol., 2009, 52, 156-163.

19. Raskin I., Role of salicylic acid in plants. Ann. Rev. Plant Physiol. Plant Mol. Biol., 1992, 43, 439-463.

20. Satraj A., Masud T., Abbasi KS., Mahmood T., Ali A., Effect of different concentrations of salicylic acid on keeping quality of apricot cv. 'Habi' at ambient storage. J. Biol. Food Sci. Res., 2013, 2, 66-78.

21. Sayyari M., Castillo S., Valero D., Díaz-Mula H.M., Serano M., Acetyl salicylic acid alleviates chilling injury and maintains nutritive and bioactive compounds and antioxidant activity during postharvest storage of pomegranates. Postharv. Biol. Technol. 2011, 60, 136-142.

22. Shafiee M., Taghavi T.S., Babalar M., Addition of salicylic acid to nutrient solution combined with postharvest treatments (hot water, salicylic acid, and calcium dipping) improved postharvest fruit quality of strawberry. Sci. Hortic., 2010, 124, 40-45.

23. Srivastava M.K., Dwivedi U.N., Delayed ripening of banana fruit by salicylic acid. Plant Sci., 2000, 158, 87-96.

24. Stanley J., Marshall R., Ogwaro J., Feng R., Wohlers M., Woolf A., Postharvest storage temperatures impact significantly on apricot fruit quality. Acta Hortic., 2010, 880, 525-532.

25. Turner J.G., Ellis C., Devoto A., The jasmonate signal pathway. Plant Cell, 2002, Suppl., 14, 153-164.

26. Valero D., Diaz-Mula H.M., Zapata P.J., Castillo S., Guillen F., Martinez-Romero D., Serrano M., Postharvest treatments with salicylic acid, acetylsalicylic acid or oxalic acid delayed ripening and enhanced bioactive compounds and antioxidant capacity in sweet cherry. J. Agric. Food Chem., 2011, 59, 5483-5489.

27. Wang L., Chen S., Kong W., Li S., Archbold D., Salicylic acid pretreatment alleviates chilling injury and affects the antioxidant system and heat shock proteins of peaches during cold storage. Postharv. Biol. Technol., 2006, 41, 244-251.

28. Watkins C.B., Ekman J.H., How postharvest technologies affect quality. 2005, in: Environmentally Friendly Technologies for Agricultural Produce Quality (ed. S.B. Yehoshua). Taylor \& Francis, CRC Press, Boca Raton, FL, pp. 447-491.

29. Yao H.J., Tian S.P., Effects of pre- and postharvest application of SA or MeJA on inducing disease resistance of sweet cherry fruit in storage. Postharv. Biol. Technol., 2005, 35, 253-262.

30. Zheng Y., Zhang Q., Effects of polyamines and salicylic acid postharvest storage of 'Ponkan' mandarin. Acta Hortic., 2004, 632, 317-320.

Submitted: 7 October 2015. Revised: 1 January and 5 March 2016. Accepted: 20 April 2016. Published on-line: 4 November 2016. 